\title{
Dossiê
}

\begin{abstract}
Resumo
A partir do material clínico apresentado pela analista de uma menina com TE $A$, outra analista realiza reflexões centradas na primeira etapa do trabalho, focando-se, principalmente, nas sensações e na relação corpo a corpo. Na medida em que o afeto experienciado, assim como o encontro com o outro e seu desejo, é o que outorga sentido à experiência sensorial, a ferramenta fundamental nessa etapa do trabalho será a utilização da própria percepsão e afetividade, colocadas a serviço de captar os minimos signos e convertê-los em sinais. São analisadas as formas de intervenção e a modalidade interpretativa da analista, que possibilitam experiências novas e fundantes do psiquismo, por meio das quais se vão produzindo movimentos de simbolização.

Descritores: autismo; caso clinico; técnica de análise de crianças; afeto; simbolização.
\end{abstract}

\section{REFLEXÕES PSICANALÍTICAS SOBRE UM CASO COM TRANSTORNO DO \\ ESPECTRO AUTISTA (TEA)}

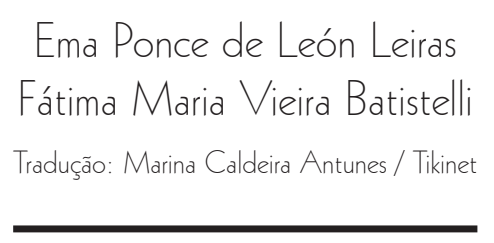

DOI: http://dx.doi.org/10.11606/issn.1981-1624.v19i2p277-293

\section{Introdução}

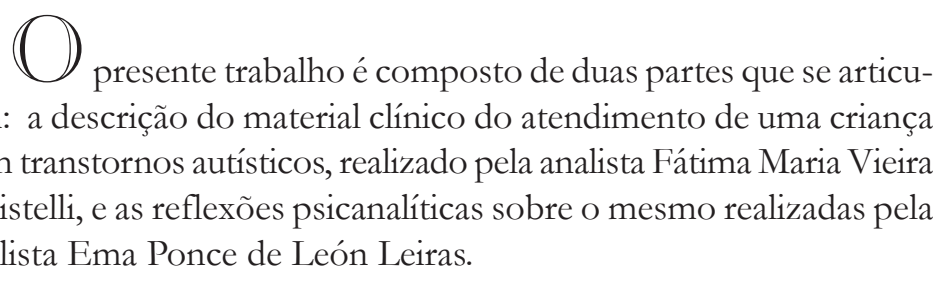

Psicanalista. Membro titular da Associacão Psicanalítica do Uruguai e diretora da Clínica del Niño - Centro del Adolescente, Montevidéu, Uruguai.

- - Psicanalista. Membro filiado do Instituto de Psicanálise da Sociedade de Psicanálise de São Paulo, São Paulo, SP, Brasil. 


\section{Caso clínico}

A criança, a quem chamarei de Laurinha, começou a análise com 3 anos e 6 meses de idade, em setembro de 2002. Os pais relatam que, quando Laurinha estava com pouco mais de um ano, passaram a notar uma defasagem em relação às crianças da mesma faixa etária. Ela havia aprendido a andar, mas a linguagem mostrava-se cada vez mais atrasada e ela não se relacionava com outras crianças. Quando me procuram, ela ainda não tem linguagem verbal, pronuncia alguns sons, aparentemente sem sentido. Muitas vezes fica emitindo esses sons, com o olhar "perdido". Não chama as pessoas, nem mesmo os pais, não fala papai e nem mamãe. Quando quer algo, busca a pessoa pela mão. Aceita colo, deixa-se abraçar, mas não abraça de volta e parece entender o que lhe é dito. Na ocasião, a mãe ainda lhe disponibiliza o seio na hora e no lugar que Laurinha buscar, é um seio á disposição, como se fosse parte dela. A mãe relata que fica muito difícil para os pais colocarem limites à filha, pois Laurinha "desmorona", se desespera demais, assim eles a deixam fazer quase tudo o que quer. Ela tem bem estabelecido o controle dos esfíncteres, o pai diz que a questão da higiene sempre foi algo muito importante para a mãe. No início, só fazia suas necessidades se lhe colocassem a fralda. Em casa, tira a roupa toda, com bastante frequência. Acumula brinquedos nos cantinhos, sendo que anteriormente eram sapatos. Gosta de pular, subir nas coisas, assistir filmes da Disney, e imita algumas cenas, por exemplo: nas cenas de medo se esconde, se a pequena sereia chora, ela faz que chora como ela. Muitas vezes não atende quando é chamada e tem medo de lugares muito amplos, mas também dos fechados, como o cinema. Está numa escola comum, mas fica totalmente ausente, muitas vezes fica só na porta da sala, não interage com nenhuma criança, fica andando a esmo pelo pátio.

Iniciamos o atendimento com a Laurinha comparecendo três vezes por semana. Nos primeiros encontros ela perambulava pela sala, mas não parecia estar exatamente interessada em conhecer o espaço, não era curiosidade, era um andar como que sem objetivo, e mexia em algumas coisas que chamassem sua atenção, coisas que pareciam ter um apelo mais sensorial. Depois de um tempo em que manipulou sensorialmente os brinquedos, tocando, apertando, começa uma atividade com eles: levá-los para cima da mesa ou do divã e lançá-los, emitindo um grito. Depois que todos caem ao chão, repete a cena 
por muitas vezes, alguns dias durante toda a sessão. Ela não me olha, emite vários sons, mas a única palavra que eu distingo é o "não", que é pronunciado diversas vezes. Eu falo algumas coisas do tipo: eles estão caindo, assustados, gritam aflitos etc. Acho que eram falas só para me manter pensando, e que talvez para ela dessem a dimensão de que eu continuava ali. Eu me mantinha sentada, observando, e as poucas ocasiões em que tentei chegar mais perto fisicamente, ela disse "não" firmemente, mas sem me olhar. Assim eu ia procurando me aproximar, sempre atenta à distância que ela considerava segura. Em algumas sessões ela interrompia essa atividade para deitar no divã e ficar olhando o ventilador girar, ou olhar para cima e falar, sorrir ou mesmo rir.

Depois de um tempo, ela descobre água na varanda da minha sala e passa a mexer nela, encher o balde, entrar nele. Para isso, tira toda a roupa, deita no chão molhado, numa atividade totalmente de exploração sensorial. Não me olha e só me busca, com as mãos, se algo não lhe agrada, como, por exemplo, acabar a água do balde. Eu vou tentando me aproximar e dar alguns contornos a essa vivência, a fim de que não fiquem apenas ao nível do sensorial: mostrar a marca que seus pezinhos fazem no chão, ou a marca da mão molhada. Nomeio as partes do corpo que vão ficando molhadas. Invento algumas musiquinhas relacionadas às atividades dela no momento. Ela vai, muito lentamente, se interessando por essas minhas observações. Passa a me olhar quando eu canto, a me mostrar coisas que parecem chamar sua atenção, me pega pelas mãos para acompanhá-la na varanda. Inclusive seu rosto parece estar adquirindo um ar mais humanizado, menos estranho.

Já estamos com seis meses de atendimento, e agora ela começa a não querer ir embora, se digo que é hora de irmos, me joga os sapatos, tenta me bater, me morder. Falo calmamente com ela nessas ocasiões, e, muitas vezes, sai chorando, no meu colo, agarrada ao meu pescoço, vivendo momentos, não mais de raiva, mas de muita dor.

Ela passa também a só entrar e sair da sala se for no meu colo. Não quer mais transpor esse espaço com as próprias pernas. Eu a carrego porque sinto que precisa disso. Inaugura uma nova atividade, que é pegar a manta de lã que fica sobre o divã e passar algumas sessões inteiras toda coberta, debaixo da manta, no meu colo, e faz questão de colocar o seu ouvido de encontro ao meu peito, penso que para escutar meus batimentos cardíacos e o ritmo da minha respiração. Começa a pronunciar palavras como "mama", "papa", mas nem sempre direcionada à pessoa correspondente. Chama-me ora de um, ora de outro. Fica muitas sessões assim. No entanto, intercala esses momentos com vivências com a água, para onde agora já leva os brinquedos, que parecem interagir, num brincar mais simbólico. Ora ela os joga 
na água como se pulassem na piscina e faz carinha e som de prazer, como se os bonecos é que o fizessem, ora faz como se os afogasse e gritassem por socorro. Nessa ocasião já estamos com oito meses de trabalho. Ela já fala algumas palavras que são possíveis de serem entendidas, sempre em relação á brincadeira, nunca comigo. Muitas vezes, quando desce do meu colo, brinca com os objetos dentro dos meus sapatos, que ela descalça quando chega à sessão. Essa brincadeira é meio mecânica e repetitiva. A turma dos brinquedos é: um coelho de pelúcia, um fantoche de pano, duas roupinhas e uma toalha. Usados todos como personagens. Às vezes ela interrompe a brincadeira e sobe no meu colo, se aconchega, me toca. E depois de um tempo sai andando. Penso que precisa me ter disponível para ir e vir, ser neném e crescer. Entrar e sair e saber que eu me encontro ali.

Depois de um tempo, põe a manta no meu corpo e brinca em cima de mim, trazendo brinquedos para o meu colo. Os bichinhos interagem, mas é tudo no meu colo, a sessão inteira. Aos poucos vai deixando o meu colo e brincando numa "cabana" que faz embaixo das minhas pernas, também usando a manta. Empurra as minhas pernas para que fiquem abertas e brinca literalmente no meio delas, com a cabeça encostada em mim. Leva vários brinquedos para lá e passa a sessão inteira assim. Aos poucos vai podendo sair desse espaço entre as minhas pernas e apropriar-se da sala, dos outros espaços. Muitas vezes acontece de a brincadeira se passar dentro dos meus sapatos, que ela sempre no início das sessões vem tirar dos meus pés, assim como tira os dela. Em outras ocasiões, brincou pela sala calçando os meus sapatos. Enfim, é uma separação, um desgrudar-se, que vai ocorrendo progressivamente, num ritmo proposto por ela, aceito e respeitando por mim.

No entanto, todos esses desenvolvimentos são intercalados por sessões nas quais eu a sinto totalmente ausente, distante de mim. Tento buscar uma brecha, algo comum entre nós, e parece que não encontro nada. Sintome excluída, à parte, não pertencente, não existindo. Ela fala na "sua língua estrangeira", não me olha, parece que não me escuta, mexe nos objetos costumeiros, chaveiros, panos, mas nada parece ter nexo, é bizarro. Essas são sessões bem difíceis e nas quais eu preciso de muita perseverança para não desanimar. Mas se aguento, depois de um tempo, ela volta. E esses afastamentos vão ficando cada vez mais raros, mas são substituídos por outra forma de me anular, que é querer que eu faça as coisas exatamente do seu jeito, uma imposição que é muito mais do que teimosia: não há brechas para algo diferente daquilo que ela quer, e essas situações são muito difíceis para nós duas. É um período de tirania. Ela exige as coisas. Grita e se desespera se não atendo, e eu vou pondo os limites, os meus, os da situação e os da realidade. São sessões difíceis, às vezes me deixam 
bastante irritada. Mas sobrevivemos também a essa temporada, e aos poucos ela vai aceitando melhor os limites.

O vocabulário da Laurinha já aumentou muito, mas apresenta dois tipos de fala. Quando fala a "palavra correta", no momento adequado, usa um tom de voz mais grave, como se não fosse ela, e quando a fala é mais bizarra ou confusa, fala com sua voz de menininha. Inclusive na sala de espera me chama de Fátima, sob a supervisão da mãe e com a voz diferente. Na sala me chama de "mamãe" ou "papai" e com a sua voz mesmo.

Descobre os lápis na caixa e eu proponho que desenhemos. Estamos com quase três anos de atendimento. Eu desenho e ela pinta. A partir daí passa a querer isso todas as sessões. Tinha que ser todas as vezes os mesmos desenhos, pintados da mesma cor. Vou sugerindo pequenas alterações, que ela vai aceitando e se arriscando a inventar também algumas. Começa ela também a desenhar, e suas produções são boas. Seu vocabulário aumenta a cada dia, fala algumas palavras erradas, mas já se comunica verbalmente. Começa a me chamar pelo meu nome, sua fala passa a fazer mais sentido e passa a usar os pronomes pessoais.

Começa a teatralizar as brincadeiras, pede que a vista de princesa, ou de sereia, e o importante é que possamos improvisar com o material que temos disponível. No início ela ficava muito desesperada quando o efeito não era do jeito que ela esperava, gritava, se desesperava, queria me bater, mas aos poucos vai aceitando as nossas possibilidades e se permitindo aproveitar a brincadeira e o faz de conta.

Depois passamos pela fase de contar estórias, ela me pede para ler livrinhos e depois ela usa os brinquedos para reproduzir a estória “à sua moda". Já se passaram quatro anos, Laura está com sete. Frequenta uma escola normal onde a classe é bem pequena, mas corresponde à série que deveria estar para a idade que possui. Tem coleguinhas, me conta, ainda com certa dificuldade de se explicar bem, os acontecimentos que lhe são importantes. Algumas vezes fala como se eu estivesse estado lá e presenciado a cena, então precisamos de um tempo maior de conversa a fim de se fazer entender. Agora traz bonecas de casa que "brincam" com as da caixa e também se despedem ao irem embora. Já fala de saudades, ciúmes, medo. Nas brincadeiras aparece a questão das diferenças sexuais, conversamos sobre e brincamos com o tema. Terminar as sessões continua difícil, ela tenta ganhar tempo, criar alguma situação, mas já tem consciência de que nosso horário termina. 
As brincadeiras com os bichinhos e bonecos da caixa estão cada vez mais simbólicas. Aparece voracidade, medo, ciúmes, briga, acordos, casamentos e cada vez mais ela pode ir se soltando de repetir cenas dos livros e ir inventando a sua própria estória. Os animais têm nome e relações entre eles. Em 2007, com oito anos, usa a Barbie que tem na caixa e faz "novelas", são estórias que se prolongam por muitas semanas. Tem vários personagens e uma trama. No final da sessão, fala que continua no próximo capítulo, e sempre retorna, dando continuidade e vida à estória.

Começa a trazer sempre uma gatinha de casa, que tem nome e tudo, mas que não brinca junto, só a acompanha. Depois essa gata é substituída por outro bichinho de pelúcia. Anda com ele para todos os lados. Leva na escola escondido na mochila, pois tem medo que outros vejam e "pague mico" (sic). Na escola quase não tem amigos, só colegas de classe. Nunca foi na casa de ninguém e não convida ninguém para a dela. Vai a festinhas, mas o relacionamento com amigos é difícil. Acho que esses bonecos são os seus amigos. Em 2008, com nove anos, conversa comigo sobre guardar seus brinquedos de casa. Vem com o bicho de pelúcia, mas quando entra na sala de atendimento, joga-o displicentemente no divã e às vezes no chão. Eu relaciono esse comportamento com o querer e ter medo de se ver livre dele, dessas coisas de menininha. Ela diz que decidiu guardá-lo para um dia dar para sua filha.

Deixa de trazer os bonecos e passa a trazer uma bolsinha com batom, quer se ver crescida, fala de pré-adolescência, acho que se baseia no irmão. Mas, ainda tem que ser concreto. O crescimento está na bolsa. É essa agora sua companheira. Leva-a para todos os lugares, até dentro da mochila, na escola. Durante muito tempo ficou com essa bolsinha para lá e para cá. Conversamos muito sobre isso. Pois é como se ela não existisse sem essa bolsinha. Nessa época, passa a fazer objetos com biscuit. É muito hábil e criativa, e suas produções são muito boas. Faz algumas bonecas de biscuit e cria uma família com elas, interagindo com as da caixa. Elas vão à escola, brincam e é através dessas bonecas que me conta as aflições e medos que passa na escola: o de não ser aceita, o de se achar diferente, de não conseguir chegar nas pessoas, de se sentir preterida etc.

Há mais ou menos um ano, voltamos aos livros. Só que agora são livros de pré-adolescente mesmo. Fala de paixão, de namoro, de primeiro beijo, de menstruação. Ela menstruou aos 11 anos e foi tranquilo. Incrível que haja ocorrido logo depois de eu ter tido a ideia

282 Estilos clin., São Paulo, v. 19, n. 2, mai./ago. 2014, 277-293. 
de trazer um livro de estória no qual a menina vivia esse dilema. Então quando ela menstruou, contou-me com toda naturalidade. Através desses livros me fala de suas dúvidas sobre o futuro. Se um dia alguém vai querer namorar ela, se ela vai beijar na boca. Se eu já havia namorado na idade dela. Ou da dúvida de como os pais começaram a namorar, se o irmão já beijou na boca ou não. Lemos essas estórias numa posição interessante. Eu sentada na ponta do divã e ela encostada em mim, mas de costas. Continua com dificuldade em ter amigos. Esse ano fez amizade com uma garota que acabou de entrar na escola. Parece que fica mais fácil se aproximar das crianças que chegam e ainda não estão enturmadas. Laurinha acabou de fazer treze anos e está cursando a $7^{\mathrm{a}}$ série do ensino fundamental.

Atualmente, Laurinha já está com catorze anos e quatro meses. Ainda lemos livros, mas também conversamos bastante. Tem dois amigos mais próximos, que apreciam o mesmo tipo de filmes e seriados que ela e trocam informações, dicas, compartilham achados. Já acessou a Internet na minha sala para me apresentar esses filmes e os personagens dos quais comenta. Gosta, mas não é uma obsessão. Fala muito da família agora e diferencia o comportamento de cada um na relação com ela. Está no ultimo ano do ensino fundamental, e muitas vezes me conta que se surpreende com isso. Outro dia quis desmanchar a caixa, que nunca mais usou, mas que eu guardava esperando que ela a desmanchasse, e já a havia convidado para tal em algumas ocasiões oportunas. Ela sempre deixava para depois. Há mais ou menos um mês desfez a caixa, quis olhar todos os brinquedos, ler as estórias que havia inventado, e eu fiquei impressionada de como ela se lembrava de coisas que fizemos juntas, até mesmo na época em que ainda quase não falava: da atividade dos desenhos, das fantasias de sereia, das cenas que fazia com os animais da caixa aos sete anos. Essa sessão foi muito rica. Enfim eu a vejo crescer a cada dia.

\section{Reflexões sobre o caso clínico}

É um desafio muito estimulante comentar este material clínico excepcional, que nos permite acompanhar os passos, que vacilam, desconcertam e comovem, de um processo analítico de uma 
menina com funcionamentos autistas, no decorrer de dez anos.

Quando li esse material, lembrei do famoso relato de St. Exupéry (1943/2000), com suas belas metáforas sobre os encontros. O autor dirá sobre o Pequeno Príncipe: "Foi difícil entender de onde ele vinha"... "habitava um planeta pouco maior que ele" (St. Exupéry, 1943/2000, pp. 4-5) ${ }^{1}$. O Pequeno Príncipe, por sua vez, se recorda de uma rosa que um dia lhe disse: "Não tenho medo dos tigres, mas tenho horror às correntes de ar. Você não teria uma redoma para me proteger?" (St. Exúpery, 1943/2000, p. 9$)^{2}$. O analista deve saber utilizar as "redomas" requeridas, como uma função para-excitação materna, tanto para criar telas protetoras da extrema fragilidade, como para saber retirá -las quando for possível enfrentar a solicitação do vínculo e os perigosos "tigres" da vida pulsional.

Estas palavras e imagens transmitem algo próximo à atmosfera emocional deste encontro, marcado pela capacidade da analista de sustentar o enigma, o desejo de compreender, a disponibilidade, a espera paciente por ser encontrada e ao mesmo tempo a busca ativa por encontrar essa menina desconectada e perdida, de se comunicar por meios não verbais, próximos ao corpo, e, quando possível, por meio de palavras. A comunicação vai nascendo porque todos esses meios são portadores de emoções e afetos, modulados delicadamente, próximos ao que Laurinha podia ir recebendo e 
processando em cada encontro. Assistimos durante o processo, através dos pequenos-grandes, ao nascimento e crescimento de um sujeito psíquico.

Os poucos dados apresentados sobre o ambiente de Laurinha nos fazem pensar em desajustes importantes entre a menina e seus pais, ressaltando-se a falta de limites e o peito da mãe que está presente o tempo todo, impedindo a falta e o desejo. Apesar dessas falhas, não podemos hoje imaginar que esses quadros tão graves sejam responsabilidade exclusiva do ambiente. Há consenso sobre a etiologia plurifatorial, a convergência de fatores constitucionais e ambientais e a relação de feedback que se estabelece entre eles. Normalmente os pais não estão preparados para enfrentar a frustração que produzem as respostas desconcertantes ou a falta de resposta dessas crianças, e se criam circuitos de relação patológicos que impedem uma transformação.

Quando assistimos a processos como o de Laurinha, nos perguntamos o que o encontro analítico oferece que os pais não podem ou não puderam oferecer. A posição do analista possui vantagens enquanto uma relação que está mais livre dos ideais e das feridas narcisistas que sofrem os pais. Ele pode aceitar essa menina tal como ela é, porque sua função está atravessada pela castração simbólica. Isso lhe permite oferecer-se como um objeto disponível, mas não intrusivo. Esse quadro possibilita uma relação bastante próxima, fortemente corporal e, no entanto, discriminada, com limites colocados em jogo a cada sessão no momento da separação. É uma relação que não está habitada pela culpa e pelos afetos intensos de ódio e frustração não metabolizados. Os afetos se mostram de forma mais atenuada que nos pais e podem ser pensados no contexto da transferência.

Mas, sobretudo, o que permanece específico da psicanálise com esses pacientes, é a posição do analista com respeito à subjetividade. $\mathrm{O}$ analista antecipa um lugar de sujeito, do qual a criança irá se apropriar pouco a pouco.

Escolhemos como foco a etapa inicial do processo, já que ela marca uma diferença no trabalho analítico em relação a outras patologias da infância. Nessa etapa, vemos que a relação com o mundo dos objetos e das sensações exerce maior atração que as pessoas. Também é muito característica a etapa na qual a relação corpo a corpo é o eixo da experiência analítica. A temática do peculiar funcionamento sensorial e a importância do corpo no 
trabalho com esses pacientes me interessa particularmente. Essa escolha supõe um recorte importante e deixa de lado muitos aspectos interessantes a serem pensados e conceitualizados.

Todos os autores psicanalíticos que têm abordado o tema do autismo descrevem essas crianças como imersas em um mundo sensorial, e têm desenvolvido hipóteses a respeito. Para contextualizar alguns comentários, queremos recordar e relacionar dois aspectos da teoria freudiana: a importância do perceptivo na constituição do psiquismo e a conceitualização dos afetos como sinais. Para Freud, as sensações que proveem do mundo exterior estão na origem da consciência, dos processos mnésicos e da representação. Em 1915, em "O inconsciente" (Freud, 1982a), ele se refere ao afeto como um processo de descarga cujas manifestações finais são percebidas como sensações com qualidades de prazer ou desprazer. Ou seja, Freud estabelece uma relação entre as sensações e os afetos, fixada no corpo, mesmo que se manifestando psiquicamente. Em 1923, o "Eu e o Id” (Freud, 1982b) nos diz que o Eu deriva de sensações corporais, principalmente as que partem da superfície do corpo, e estabelece sua conhecida concepção de que o Eu é, antes de tudo, um Eu corporal.

Em 1926, em "Inibição, sintoma e angústia” (Freud, 1982c), Freud postula os afetos como sinais para o Eu. A expansão deste modelo enfatiza a função reguladora que o afeto cum- pre no aparelho psíquico. Entretanto, em uma perspectiva intersubjetiva, os afetos são sinais não apenas para o Eu, mas também para o outro. São os sinais mais importantes na relação com o outro. É a emoção, o afeto experimentado, o que outorga sentido à experiência sensorial. Porém, não é concebível emoção nem afeto fora da relação e da adjudicação de sentido com o outro.

Também queremos destacar o papel que tem o desejo materno e a sexualidade em interjogo com a sensorialidade inicial. A zona sensorial se transformará em zona erógena a partir do encontro com a mãe e seu desejo. Diz Piera Aulagnier: "É necessário que a mãe experimente um prazer psíquico, com seus componentes erotizados, para que o infans possa sentir plenamente sua própria experiência de prazer" (Aulagnier, 1991, p.160) ${ }^{3}$ e a princípio "o objeto apenas existe psiquicamente por seu mero poder de modificar a resposta sensorial (e, consequentemente, somática) e, por essa via, de atuar sobre a experiência psíquica" (Aulagnier, 1991, p.141) ${ }^{4}$. A criança autista impõe ao objeto uma categoria onde o poder sensorial é o que o torna existente (Aulagnier, p.147). Falta construir um corpo erógeno, unificado, através das experiências de prazer com o objeto.

Antes de expor nossas hipóteses, queremos salientar que a Psicanálise conta com desenvolvimentos teóricoclínicos bastante ricos sobre o autismo. Tal como acontece com muitas 
de nossas teorias, devemos distinguir quais são as de índole especulativa e considerá-las como hipóteses particulares e não gerais. Um dos riscos é reproduzir as teorias sobre a constituição psíquica para se realizar uma leitura do autismo como "o negativo" daquilo que deveria ter acontecido, com tendência a uma etiologia exclusivamente psicógena. É fato que encontramos uma série de "ausências” essenciais e padrões atípicos em relação ao desenvolvimento normal, mas encontramos fundamentalmente a ausência de uma subjetividade. A antecipação da ideia de um sujeito na mente do analista é condição de humanização, e não se refere a uma pré-concepção teórica, mas requere que o analista se coloque em jogo de corpo e alma, a partir de sua própria subjetividade.

Ao mesmo tempo, nos parece fundamental para contrastar as teorias existentes com a clínica, e para desenvolver as próprias, prestar atenção no que surge no campo das investigações atuais, realizadas com o rigor requerido e considerando a dimensão subjetiva, a perspectiva interdisciplinar, assim como a integração dos aspectos psicoanalíticos e neurobiológicos. Na última década, vêm sendo reali; zadas investigações relativas às falhas constitucionais no processamento sensorial das crianças com transtornos do espectro autista. É o caso de Stanley Greenspan, psiquiatra e psicanalista de destaque, que apresenta uma hipótese interessante: a de que, 
nesses transtornos, se produz um déficit constitucional na conexão do afeto que acompanha as experiências sensoriais e motoras, dando lugar a modalidades peculiares de reação e processamento dos estímulos (Greenspan, 2001).

No comportamento de Laurinha se observa uma "hiporreação" aos estímulos, o que produz uma busca de sensações, no meu modo de ver, destinada a ter a experiência mais básica de existir como "corpo que sente". A "hiper-reação", pelo contrário, faz com que se evite os estímulos que se mostram intoleravelmente excitantes. Frequentemente as duas reações ocorrem de maneira combinada: o "sentir" não aparece ou transborda. Acreditamos que, efetivamente, o que falha nessas experiências sensoriais é a ligação com as emoções e afetos que normalmente as acompanham, dificultando processos de inscrição psíquica. Estes afetos só podem ser gerados e regulados no encontro com o outro. Se esses encontros são frustrados, pelas limitações da criança e pelas respostas do ambiente, não se produz a significação afetiva da experiência sensório-motora precoce, que é o primeiro elo da simbolização.

$\mathrm{Na}$ relação com os objetos, observamos claramente em Laurinha a importância do tocar, como uma forma de dar existência aos objetos e a si mesma. Mesmo que aconteça com os objetos inanimados, o contato com o outro é ameaçador, por conta da perda de controle conferida pela intensidade das sensações que os afetos trazem. O outro é portador de estímulos cuja excitação a criança autista não pode processar e modular.

$\mathrm{Na}$ sua primeira interação com os objetos do consultório, se limita a atirá-los e vê-los cair, enquanto grita. Parece uma atividade pré-simbólica, na qual atua sua relação com o mundo. A analista nomeia alguns significados possíveis, instaurando a violência primária necessária quando há outro portador de sentidos. Equivale à resposta de uma mãe a um pranto aflitivo: "o que está acontecendo, meu bebê está assustado? Estou aqui para que você não se sinta sozinho". A queda e o susto são significantes que poderão logo ser resignificados, mas as emoções transmitidas pela analista se expressam e deixam marcas no aqui e agora, com as qualidades de sua presença sensorial: voz, movimentos, afetos, que Laurinha não possui. Trata-se de uma função de espelhamento que se vai instalando em um espaço potencial, disponível para ser usada. A função de espelhamento é desenvolvida por distintas concepções teóricas, todas elas destacando a importância do olhar do outro e o reflexo de "si mesmo" 
oferecido à criança, tanto em relação a seus estados afetivos quanto a sua imagem corporal, promovendo um processo integrador do psique-soma, assim como processos identificatórios. Acreditamos que aí habita a ferramenta fundamental da análise nessa etapa: a utilização da própria percepção e afetividade colocada a serviço de captar signos mínimos e convertê-los em sinais. A modalidade da presença, a forma de estar, é a base da qual proveem as intervenções do analista: seus pensamentos, seus atos, suas palavras para esse paciente e não para outro. $\mathrm{O}$ inconsciente que está em jogo no momento é o do próprio analista ${ }^{5}$.

Enquanto a criança normal repete suas brincadeiras, mas as vai transformando porque o outro é aceito desde o início como um agente transformador, o ato de repetir de um modo fixo e estereotipado uma experiência mostra a enorme dificuldade de transformação da mesma, porque não se introduz a diferença por meio da presença do outro. No início, Laurinha mostra atividades autocentradas: assim como toca, lança objetos, se escuta gritar, fala e ri para si mesma, olha o movimento rítmico do ventilador. Nesse contexto, nos chama a atenção o uso do "não", que Laurinha utiliza de forma apropriada para expressar repúdio à proximidade da analista. No desenvolvimento normal, a criança registra o "não" a partir da frustração do objeto, mas sua utilização na linguagem supõe uma comunicação à distância. Surpreende seu uso em Laurinha, se pensamos nos pais com dificuldades para impor limites, que representa, talvez, um embrião de si mesmo que pode se enunciar a partir da negação. Este tipo de signo mais evoluído, em contraste com um desenvolvimento global perturbado, é frequente nessas crianças e abre uma brecha de esperança a respeito do prognostico.

As atividades de Laurinha com a água são parte de sua busca de sensações prazerosas muito primárias, que evocam o contexto intrauterino. É interessante a consciência da existência do outro quando ela não pode solucionar algo por si só. Mesmo sendo um uso instrumental do outro, também há uma noção de que a ação do outro pode promover uma mudança desejada. As intervenções da analista são de formulação simples, como devem ser, e ao mesmo tempo são bastante finas e de efeito amplificador, ao relacionar as marcas dos pés nas superfícies ou as mãos molhadas, assim como as marcas água em partes do corpo. São intervenções que condensam muitos níveis: a relação com o próprio corpo e seu movimento com a exterioridade, os efeitos do elemento externo no próprio corpo, a diferenciação "eu e não-eu", a causalidade. As marcas visíveis estendem uma ponte até as marcas psíquicas, mediadas pela palavra e o afeto do outro, movimentos fundantes da simbolização. Nesse momento de abertura dos sentidos até as emoções, a analista 
incorpora oportunamente a musicalidade da voz, o prazer compartilhado e, desta forma, vemos emergir em Laurinha o interesse pela analista, o início de uma comunicação de ida e volta. Temos então, aos seis meses de tratamento, possivelmente uma bebê de seis meses no consultório, que busca morder e bater, podendo esboçar o amor-ódio estruturante, a angústia da separação.

A etapa em que se cobre com a manta nos evoca um processo relativo à necessidade de criar uma envoltura corporal própria, mas a partir do contato corporal com a analista. Recriação de uma cena intrauterina ou de recém nascida, buscando os referentes da respiração e o ritmo cardíaco da analista, identificadores muito primários do objeto materno, que produzem um efeito calmante. Lembremos que Winnicott denomina verdadeiro self a aquele que "surge dos tecidos e das funções corporais, inclusive da ação do coração e da respiração” (Winnicott, 1960) .

Assim mesmo, considerando a contribuição de Winnicott, podemos dizer que as sensações corporais se mostram afetadas pelas qualidades do holding e do handling que é capaz de prover a figura materna. Nesse caso, a analista é a que está conferindo novas qualidades ao contato físico a partir de sua modalidade de apoio e contenção. Laurinha começa a se referir à analista como mamãe e papai, se dando conta do reconhecimento dessas funções a partir de suas experiências com ela. Ao mesmo tempo, vai podendo esboçar um jogo em que aparecem qualidades de prazer-desprazer. Junto com todos esses avanços, se intercalam momento nos quais Laurinha retoma seus funcionamentos autistas. São momento de desesperança para a analista, de espera paciente, de sobrevivência. Para Laurinha é um ir e vir até o objeto, buscando o contato e se afastando, armando a ausência em presença do outro.

É muito comovente todo o processo de brincadeiras que se desdobram sobre o corpo da analista e entre suas pernas, ou dentro de seus sapatos. É comovente porque dá conta de experiências novas e fundantes do psiquismo, e da peculiar convergência de processos pertencentes a distintos momentos do desenvolvimento afetivo. Laurinha brinca com os brinquedos, em movimentos progressivos de simbolização, como um bebê que brinca com o corpo da mãe enquanto é amamentado, carregado no colo, banhado etc. Ou seja, aqui se juntam de modo singular os primeiros objetos a serem simbolizados pelo bebê, segundo Klein, partes do próprio corpo e do corpo materno, como suporte real do jogo simbólico com outros 
objetos. É como se Laurinha condensasse nesse jogo processos do começo da infância e outros mais evoluídos. Certamente com movimentos progressivos e regressivos entre a equação simbólica e o símbolo, segundo Segal, ou entre a chamada simbolização primária e secundária, segundo Roussillon ${ }^{7}$. Não há distância do objeto primário, é necessário que seu corpo esteja presente como um cenário no qual ao mesmo tempo "brinca" com outros objetos que passam a ser símbolos.

Como reflexão final, diremos que o processo de Laurinha mostra que para a criação de símbolos é necessário um vínculo, são necessários dois elementos que possam estar ausentes um do outro e logo presentes, para que se possa unir as partes e co-criar um significado. Esta alternância com um mesmo objeto, mais a consciência da alternância, permite que o objeto seja o mesmo quando está presente e quando está ausente. A constancia do objeto na mente é condição e efeito de simbolização. Isso acontece se ele é fruto de uma experiência co-criada, se as vivências são compartilhadas e significativas para ambos. A simbolização tem lugar em um vínculo em que o outro seja fonte de emoções e afetos variados, prazerosos e penosos, com matizes e contrastes, mas onde predomine o prazer da presença, e que possa oferecer uma continuidade externa e interna para sustentar esses processos.

Os funcionamentos autistas podem se transformar em um encontro como o da analista com Laurinha, se aproximando com passos muito leves, partindo da sintonia dos corpos, de suas qualidades sensoriais, da comunicação não verbal, acompanhada da realidade dos sentimentos entre ambas.

Para terminar, retomaremos um diálogo entre o Pequeno Príncipe e a raposa. A raposa pedirá ao Pequeno Príncipe que a domestique, para que ela possa brincar com ele: "Você deve ter muita paciência. No começo você se sentará um pouco longe de mim, assim, no chão; eu te olharei com o canto do olho e você não me dirá nada. A linguagem é fonte de maus entendidos. Mas a cada dia você poderá se sentar um pouco mais perto" (St. Exupéry, $1943 / 2000$, p. 23$)^{8}$.

\section{RESUMEN}

REFLEXIONES PSICOANALÍTICAS SOBRE UN CASO CON TRASTORNO DE ESPECTRO AUTISTA (TEA)

A partir del material clínico presentado por la analista de una niña con TEA, otra analista realiza reflexiones centradas en la primera etapa del tratamiento, centrada en las sensaciones y la relación cuerpo a cuerpo. Dado que es el afecto experimentado y el encuentro con el otro y su deseo lo que otorga sentido a la experiencia sensorial, será berramienta fundamental del análisis la propia percepción y afectividad al servicio de captar mínimos signos y convertirlos en señales. Se analizan las formas de intervención y la modalidad interpretativa de la analista, habilitando experiencias nuevas y fundantes del psiquismo, donde comienzan a producirse movimientos de simbolización.

Palabras clave: autismo; caso clínico; técnica psicoanalitica en niños; afecto; simbolización. 


\section{Abstract}

PSYCHOANALITICAL REFLECTIONS ON A CASE OF AUTISM SPECTRUM DISORDER (ASD)

Some reflections are made by an analyst from the clinical material presented by the analyst for a girl with ASD, focusing on the first stage of treatment, which is centered in sensations and body-to-body interaction. It is the experienced affect and the encounter with the other one and his or her desire what brings meaning to the sensorial experience. The fundamental tool of psychoanalysis in this stage will be the analyst's perception and affect, at the service of perceiving minimal signs and transform them into signals. The author discusses the form of intervention and the interpretative mode of the analyst, which enables new and building psychic experiences through which symbolization movements start to occur.

Index terms: autism; clinical case; child psychonalysis technique; affect; symbolization.

\section{REFERÊNCIAS}

Aulagnier, P. (1986). Nacimiento de un cuerpo, origen de una historia. In L. Hornstein et al. (1991). Cuerpo, historia, interpretación. Piera Aulagnier: de lo originario al proyecto identificatorio. Buenos Aires: Paidós.

Freud, S. (1982a). Lo inconsciente. In S. Freud, Obras completas (Tomo XIV, pp. 153-207). Buenos Aires: Amorrortu. (Trabalho original publicado em 1915)

Freud. S. (1982b). El yo y el ello. In S. Freud (1990). Obras completas (Tomo XIX, pp. 1-63). Buenos Aires: Amorrortu. (Trabalho original publicado em 1923)

Freud. S. (1982c). Inhibición, síntoma y angustia. In S. Freud (1990). Obras completas (Tomo XX, pp. 71-164). Buenos Aires: Amorrortu. (Trabalho original publicado em 1926)

Greenspan, S. I. (2001). The affect diathesis hypothesis. The role of emotions in the core defict in autism and the development of intelligence and social skills. Journal of Development and Learning Disorder, 5, 1- 44.
Rousillon, R. (1995). Agonie, clivage e symbolisation (Collection Le fait psychanalytique). Paris: PUF.

St. Exupéry A. (2000). El principito. Disponível em http://www.vicentellop.com/TEXTOS/principito/principito.pdf (Trabalho original publicado em 1943)

Winnicott, D. (1960). La distorsión del yo en términos del self verdadero y falso. In D. W. Winnicott,w Los procesos de maduración y el ambiente facilitador (pp. 182-189). Buenos Aires: Paidós.

\section{NOTAS}

1. N. do T.: "Me costó mucho comprender de dónde venía"..."habitaba un planeta apenas más grande que él”

2. N. do T.: "no temo a los tigres, pero tengo miedo a las corrientes de aire ¿No tendrías un biombo?"

3. N. do T.: "Es necesario que la madre experimente un placer psíquico, con sus componentes erotizados, para que el infans pueda sentir plenamente su propia experiencia de placer."

4. N. do T.: "el objeto sólo existe psíquicamente por su mero poder de modificar la respuesta sensorial (y por lo tanto somática) y por esta vía, de actuar sobre la experiencia psíquica.”

5. Nos referimos ao inconsciente reprimido. O autismo coloca diante de nós um problema metapsicológico relativo ao estatuto do psíquico e das marcas ou inscriçóes. Nos processos analíticos desses pacientes, se constrói um psiquismo, algo prévio à promoçáo de processos de repressão estruturante, fenômeno frequente na análise de crianças. Na condição de hipótese, pensamos que a referida construçáo se apoia no encontro com um outro que outorgue significado aos signos, às expressôes somáticas relativas a marcas que tenham conservado um caráter predominantemente sensorial por falhas no processo de ligadura com o afeto (ausência de prazer ou excesso de dor no encontro com o objeto). Se trata de um processo 
abortado à espera de uma experiência com significação afetiva que possibilite sua integração.

6. N. do T.: "surge de los tejidos y las funciones corporales, incluso de la acción del corazón y de la respiración.”

7. Roussillon propõe uma simbolização primaria que "religa a primeira inscrição... da matéria primeira... à representação de palavra... e a inscreve no aparelho da linguagem" (1999, p. $218^{9}$. Isso supóe integrar a linguagem verbal, a linguagem do afeto, a linguagem do corpo e do ato.

8. N. do T.: "Debes tener mucha paciencia. Te sentarás al principio un poco lejos de mí, así, en el suelo; yo te miraré con el rabillo del ojo y tu no me dirás nada. El lenguaje es fuente de malos entendidos. Pero cada día podrás sentarte un poco más cerca."

9. N. do T.: "religa la primera inscripción... de la materia primera... a la representación de cosa... y una simbolización secundaria que religa una representación de cosa a una representación de palabra...y la inscribe en el aparato de lenguaje."

ema.pdl@gmail.com

Almirante Harwood, 6144

11500 - Montevideo - Uruguay.

fvbatistelli@uol.com.br

Rua Artur de Azevedo, 243

05451-000 - São Paulo - SP - Brasil.

Recebido em setembro/2013.

Aceito em março/2014. 